\title{
Rural Households Willingness to Pay for Small Ruminant Meat in South-Western Nigeria
}

\author{
Otunaiya Abiodun Olanrewaju ${ }^{1, ~}$, Ologbon Olugbenga A. Chris ${ }^{1}$, Adigun Grace Toyin ${ }^{2}$ \\ ${ }^{1}$ Department of Agricultural Economics and Farm Management, College of Agricultural Sciences, Olabisi Onabanjo University, Yewa Campus, \\ Ayetoro, Ogun State, Nigeria \\ ${ }^{2}$ Department of Agricultural Economics and Extension, College of Agricultural Sciences, Landmark University, Omu-Aran, Kwara State, \\ Nigeria
}

\section{Email address:}

aootunaiya@gmail.com (A. O. Otunaiya)

\section{To cite this article:}

Otunaiya Abiodun Olanrewaju, Ologbon Olugbenga A. Chris, Adigun Grace Toyin. Rural Households Willingness to Pay for Small Ruminant Meat in South-Western Nigeria. Agriculture, Forestry and Fisheries. Vol. 4, No. 3, 2015, pp. 117-122. doi: 10.11648/j.aff.20150403.17

\begin{abstract}
Subsistent level of indigenous small ruminant meat production in Nigeria limits its supply and consequently, accounted for its high prices. The study examined the willingness to pay for indigenous small ruminant meat in Ijebu division of Ogun state, Nigeria. A multistage sampling technique was used to select 120 rural households used for the study. The results of the descriptive and Logit regression analyses revealed that rural households head in the study area are mostly females, attained appreciable level of literacy with a means of livelihood and mostly in their middle age. These rural households consumed small ruminant meat regularly, well educated about the nutritional value of the ruminant meat, and mostly, willing to pay the market price of small ruminant meat whenever they are ready to consume the meat. Factors influencing their willingness to pay for small ruminant meat are age of the household head, occupation, distance from market, and price of small ruminant meat. The study recommends the establishment of slaughter houses and small ruminant meat market to consumption areas and in various villages to broaden the market as well as providing improved market access to producers.
\end{abstract}

Keywords: Small Ruminant, Meat, Consumption, Logit, Nigeria

\section{Introduction}

Food production in the form of meat, milk and other livestock products constitute a major group of livestock outputs. Indigenous sheep and goats are among the most important species of livestock (Shalander and Pant, 2002). About 14\% of the total value of livestock output was contributed by small ruminants (Degefu, 2003). Small ruminant production in sub Saharan Africa is an important aspect of the livestock economy; where more than $80 \%$ of rural families especially women and children keep sheep and goats (Jaitneret al., 2001; Kumar et al., 2003; Boyazoglu et al., 2005). In Nigeria, rural households keep $37.4 \%$ and $8.3 \%$ of goats and sheep respectively with an average number per owner being 6.5 sheep and5.2 goats (International Livestock Centre for Africa, ILCA, 1991).

The goat being an animal that survives most ecological zones is considered to be one of the most important protein producing animals and they provide $30-36 \%$ of the total meat consumption of the Nigerian populace annually (Gomna \& Rana, 2007; York \& Gossard, 2004)
In Nigeria small ruminants contribute an estimated $35 \%$ to the total meat supply; they are more important in the north than in the south, and more important in rural than in urban areas. Population estimates suggest there are roughly 34.5 million goats and 22.1 million sheep in the sub-humid zone of Nigeria. The major breed of sheep is the Yankasa; the West African Dwarf is the major goat breed (Nwosu, Madu, \& Richards, 2007). Due to poor management, inbreeding and inadequate nutrition, these goats are usually predisposed to a range of health problems (Kathiravan, Thirunavukkarasu, \&Michealraj, 2007).

The level of small ruminant meat consumption is expected to increase geometrically and double the current consumption level by the year 2020 (De Vries, 2008; Juma, et.al 2010). Structural change in the economy as a result of increases in urbanization, population and income growth will promote the demand for small ruminant meat; hence, create markets for animal products and encourage commercialization of livestock production (Idowu, et.al., 2012). The extent of this commercialization depends on the consumption of the products by consumers (Otunaiya \& Shittu, 2014). Meat consumption 
behavior is the deciding factor for the development of the livestock sector in general and small ruminants in particular (Thammi and Suryanarayana, 2005). Consumer tastes and preferences are reflected in the market. These are revealed through purchase decisions and price premiums that consumers pay for both visible (Langyintuo et al., 2004) and invisible characteristics of meat.

In most part of Nigeria, small ruminant are raised at subsistence scale, hence, resulting in inadequate quantity of sheep and goat meat in the market, especially during festival. This shortage in supply accounted for the high price of small ruminant meat when compared with the prices of its substitutes. This study, therefore, examined the small ruminant consumption and the willingness to pay among respondents in Ijebu division of Ogun State, Nigeria. The study specifically describes the socio economic characteristics of respondents in the study area and examines the determinants of respondents' willingness to pay for small ruminant meat.

\section{Methodology}

The study area was carried out in Ijebu division of Ogun State, Southwest geo-political zone of Nigeria. Ijebu division is one of the four divisions of the State; it comprises of five Local Government Areas (LGA). The Ijebu tribes inhabit the South-Central part of Yoruba land - a territory that is bounded in the North by Oyo State, in the East by Ondo State, and the West by Egba land.

Primary data was collected from the respondents with the aid of well structured questionnaire. Multi-stage sampling technique was employed for the purpose of this study. In the first stage, three (3) Local Government Areas were randomly selected from the division; namely: Ijebu North East LGA, Ijebu -Ode LGA and Ijebu North LGA. In the second stage, three (3) Villages/Towns from each of the selected LGA were randomly selected; namely: Ijebu North East LGA (Ilese, Atan, and Isonyin), Ijebu-Ode LGA (lgbeba, Obalende, and Olisa) and Ijebu North LGA (Ijebu Igbo, Oru and Ago-lwoye). In the final stage, households were sampled proportional to the population of the village/town. The procedure gave a total sample size of one hundred and twenty (120) respondents used in the study.

\subsection{Analytical Procedure}

Descriptive statistics and economic model were used for the purpose of the study. Descriptive statistics such as percentages, means and frequency were used to discuss the socio-economic characteristics of the respondents. The empirical analysis utilized a contingent valuation dichotomous choice methodology. A single-bounded logit model was used to explore factors affecting willingness to pay for indigenous ruminant meat. The mean price that households were willing to pay for indigenous ruminant meat was also estimated. A consumer's decision to continue buying indigenous ruminant meat (willing to pay) or not to buy given some increase in price is a binary or dichotomous mode, in which probabilistic modeling frame work can be applied. In this case, both logit and probit models can be used. Theory states that the difference in the models is related to the assumption of the error term distribution and that both yields roughly the same results for the variables of interest. Independent distributed error term in logit regression assumed to be normally distributed with zero mean and constant variance. (Hosmeret.al. 2013).Consequently a logit model was used to examine the factors affecting willing to pay for indigenous ruminant. The logit model was implicitly specified as follows:

\subsection{Logit Model}

A logistic regression model allows us to establish a relationship between a binary outcome variable and a group of predictor variables. It models the logit-transformed probability as a linear relationship with the predictor variables. More formally, let y be the binary outcome variable indicating unwillingness to pay/willingness to pay for indigenous small ruminant with $0 / 1$ and $\mathrm{p}$ be the probability of $\mathrm{y}$ to be 1 , $p=\operatorname{prob}(y=1)$. Let $X_{1}, X_{2}, X_{k}$ be a set of predictor variables. Then the logistic regression of $\mathrm{y}$ on $X_{1}, X_{2}, . X_{k}$ estimates parameter values for $\beta_{0}, \beta_{1} \ldots \beta_{k}$ via maximum likelihood method of the following equation.

$$
\operatorname{logit}(p)=\log (p /(1-p))=\beta_{0}+\beta_{1} X_{1}+\beta_{k} X_{k}+\varepsilon_{i}
$$

In terms of probabilities, the equation above is translated into (n)

$$
p=\exp \left(\beta_{0}+\beta_{1} X_{1}+\beta_{k} X_{k}\right) / 1+\exp \left(\beta_{0}+\beta_{1} X_{1}+\beta_{k} X_{k}\right)+\varepsilon_{i}
$$

where:

$y_{i}=$ Willingness to pay $(1=$ if willing, $0=$ otherwise $)$

$X_{10}=$ Distance from market $(\mathrm{Km})$

$X_{1}=$ Level of education (in years)

$X_{2}=$ Age (in years)

$X_{3}=$ Household income (N/per month)

$X_{4}=$ Dependency ratio (Ratio of non-working members to household size)

$X_{5}=$ Marital Status (Married $=1$; Others $=0$ )

$X_{6}=$ Sex $($ Male $=1 ;$ Female $=0)$

$X_{7}=$ Consumer Preference (Small ruminant $=1$; others $=0$ )

$X_{8}=$ Religion

$X_{9}=$ Occupation (Livestock farming $=1$; others $=0$ )

$X_{11}=$ Availability of ruminant meat (Available within community $=1$; Not available $=0$ )

$X_{12}=$ Small ruminant price $(\mathrm{N} / \mathrm{kg})$

$X_{13}=$ Household size (Number)

$X_{14}=$ Small ruminant meat quality perception (Better than other meat $=1$; otherwise $=0$ )

$\beta_{i}=$ Unknown parameters to be estimated

$\varepsilon_{i}=$ Independent distributed error term 


\section{Results and Discussion}

\subsection{Socio-Economic Characteristics of Rural Farm Households}

The study examines the socio-economic characteristics of the sample households both in terms of the characteristics of the household heads, household composition, living conditions and access to basic social amenities.

\subsection{Household Characteristics}

Table 1. Distribution of sampled households by Socio-economic Characteristics.

\begin{tabular}{|c|c|c|}
\hline Age-Grouped & Frequency & Percentage \\
\hline Above 30 years & 29 & 24.2 \\
\hline $31-40$ years & 36 & 30.0 \\
\hline $41-50$ years & 50 & 41.7 \\
\hline $51-60$ years & 5 & 4.2 \\
\hline \multicolumn{3}{|l|}{ Sex } \\
\hline Male & 47 & 39.2 \\
\hline Female & 73 & 60.8 \\
\hline \multicolumn{3}{|l|}{ Marital status } \\
\hline Married & 90 & 75.0 \\
\hline Single & 30 & 25.0 \\
\hline \multicolumn{3}{|l|}{ Educational status } \\
\hline Secondary school & 44 & 36.7 \\
\hline O.N.D/H.N.D & 33 & 27.5 \\
\hline University & 43 & 35.8 \\
\hline \multicolumn{3}{|l|}{ Religion } \\
\hline Christians & 77 & 64.2 \\
\hline Muslim & 43 & 35.8 \\
\hline \multicolumn{3}{|l|}{ Main occupation } \\
\hline Banker & 14 & 11.7 \\
\hline Business & 15 & 12.5 \\
\hline I T student & 4 & 3.3 \\
\hline Civil servants & 26 & 21.7 \\
\hline Teacher & 15 & 12.5 \\
\hline Farmer & 8 & 6.7 \\
\hline Marketer & 1 & .8 \\
\hline Clerk & 3 & 2.5 \\
\hline Receptionist & 2 & 1.7 \\
\hline Trader & 24 & 20.0 \\
\hline Butcher & 1 & .8 \\
\hline Cleaner & 3 & 2.5 \\
\hline Tailor & 4 & 3.3 \\
\hline \multicolumn{3}{|l|}{ Experienced } \\
\hline Below 5 years & 112 & 93.3 \\
\hline $6-10$ years & 6 & 5.0 \\
\hline $11-15$ years & 2 & 1.7 \\
\hline \multicolumn{3}{|l|}{ Family size } \\
\hline $1-3$ & 32 & 26.7 \\
\hline 4-6 & 70 & 58.3 \\
\hline $7-9$ & 18 & 15.0 \\
\hline Total & 120 & 100.0 \\
\hline
\end{tabular}

Table 1 presents the distribution of the sampled households by size as well as personal characteristics of the household heads; including age, sex, education level, marital status, religion, and main occupation. As shown in the table, a typical household in the sample is made up of 4-6 members. It is also worthy of note that most (93.3 per cent) of the household heads do not have farming as their main occupation.

In terms of age, evidence on Table 1 shows that majority (41.7 per cent) of the sampled households have the age of their household heads falling between 41 and 50 years. As much as 4.2 per cent were aged, while youths (30 years or younger) featured less prominently (24.7 per cent) among the respondents. This confirms the commonly reported aging rural farm population in Nigeria (Bah, et. al. 2003), and suggests that availability of off-farm livelihood options might be necessary to retain youths within the rural farm sector.

Table 1 further shows that 60.8 per cent of the heads of the households were females and majority ( 75.0 per cent) were married. This implies that most the household heads in the study area are either divorced or separated mothers. Meanwhile, all the household heads (100 per cent) possess some formal education, which is predominantly at the primary and secondary level; an appreciable level of literacy exists among the respondents. This is expected to enhance their ability to take full advantage of extension services, thus affecting their income generation and reduce their poverty.

\subsection{Households Living Conditions and Access to Basic Amenities}

Access to basic social amenities and living conditions are important indicators of household welfare and poverty status. Thus, this study examined these key indicators among the sampled rural farm households. The results are summarized in Table 2.

As shown in Table 2, majority of the sampled households (55\%) used both Ibadan Electric Distribution Company (IBEDC) power supply and generating set; $45 \%$ depends on IBEDC alone as the source of power. This also have implications on the level of value addition that is possible in the rural farm sector, given that most agro-processing activities requires stable electricity supply. The results in Table 2 further show that majority of the survey communities have no access to tap water but depend mainly on borehole. Majority of the respondents $56.7 \%$ used kerosene as their cooking fuel. The result also shows that most of the sampled households, in the study area, live in houses with water closet system of toilet. Majority $62.5 \%$ make use of private hospital for their health treatment and made use of designated refuse dump site to dispose their refuse.

Table 2. Distribution of households by access to social amenities and living conditions.

\begin{tabular}{lll}
\hline Electric source & Frequency & Percent \\
\hline IBEDC & 54 & 45.0 \\
Both generator and IBEDC & 66 & 55.0 \\
Water sources & & \\
Well & 6 & 5.0 \\
Pipe borne water & 18 & 15.0 \\
Borehole & 64 & 53.3 \\
Pipe borne water and borehole & 24 & 20.0 \\
Well and borehole & 1 & 0.8 \\
Well and pipe borne water & 7 & 5.8 \\
\hline
\end{tabular}




\begin{tabular}{|c|c|c|}
\hline Electric source & Frequency & Percent \\
\hline \multicolumn{3}{|l|}{ Cooking fuel } \\
\hline Kerosene & 68 & 56.7 \\
\hline Charcoal & 3 & 2.5 \\
\hline Gas & 5 & 4.2 \\
\hline Kerosene and gas & 19 & 15.8 \\
\hline Kerosene, gas and electricity & 16 & 13.3 \\
\hline Kerosene and charcoal & 8 & 6.7 \\
\hline $\begin{array}{l}\text { Charcoal, gas, electricity and } \\
\text { kerosene }\end{array}$ & 1 & 0.8 \\
\hline \multicolumn{3}{|l|}{ Toilet } \\
\hline Bush toilet & 2 & 1.7 \\
\hline Pit latrine & 29 & 24.2 \\
\hline Water closet & 89 & 74.2 \\
\hline \multicolumn{3}{|l|}{ Treatment access } \\
\hline Primary health clinic & 25 & 20.8 \\
\hline Private hospital & 75 & 62.5 \\
\hline Traditional healing & 5 & 4.2 \\
\hline Self medication/chemist shop & 3 & 2.5 \\
\hline Self treatment with herbs & 4 & 3.3 \\
\hline $\begin{array}{l}\text { Primary health clinic and private } \\
\text { hospital }\end{array}$ & 5 & 4.2 \\
\hline $\begin{array}{l}\text { Private hospital and self treatment } \\
\text { with herbs }\end{array}$ & 3 & 2.5 \\
\hline \multicolumn{3}{|l|}{ Waste disposal means } \\
\hline Bush disposal & 29 & 24.2 \\
\hline Refuse dump & 44 & 36.7 \\
\hline Government waste disposal system & 34 & 28.3 \\
\hline Bush disposal and refuse dump & 4 & 3.3 \\
\hline $\begin{array}{l}\text { Bush disposal and government waste } \\
\text { disposal }\end{array}$ & 1 & 0.8 \\
\hline $\begin{array}{l}\text { Refuse dump and government waste } \\
\text { disposal }\end{array}$ & 8 & 6.7 \\
\hline Total & 120 & 100.0 \\
\hline
\end{tabular}

Table 3. Distribution of Households by their Attitude to Small Ruminants Consumption.

\begin{tabular}{lll}
\hline Attitude to Small Ruminant Consumption & Frequency & Percent \\
\hline Do you consumed small ruminant meat & & \\
Yes & 111 & 92.5 \\
No & 9 & 7.5 \\
Why Do You Consumed Small Ruminant Meat & & \\
no response & 9 & 7.5 \\
Taste & 40 & 33.3 \\
Flavor & 17 & 14.2 \\
Nutritional value & 54 & 45.0 \\
Are you aware of the nutritional value of small & & \\
ruminant meat & 112 & \\
Yes & 8 & 93.3 \\
No & & \\
Are you willing to pay the market price of small & & \\
ruminant meat when ready to consumed & 107 & 89.2 \\
Yes & 13 & 10.8 \\
No & & \\
In case your income increases will you & & \\
consumed more of small ruminant meat & 105 & 87.5 \\
Yes & 15 & 12.5 \\
No & & \\
Do you have any close substitute you do use & & \\
instead of small ruminant meat & 110 & 91.7 \\
Yes & 10 & 8.3 \\
No & 120 & 100.0 \\
Total & & \\
\hline
\end{tabular}

The above table (Table 3) shows that majority of the respondents $92.5 \%$ regularly consumed small ruminant meats. About $93.3 \%$ of the respondents were aware of the nutritional value of the meat but only about $45 \%$ of those who regularly consumed the meat did so because of its nutritional value. About $89.2 \%$ of the respondents are willing to pay the market price of small ruminant meat whenever they are ready to consume the meat. Majority of the respondents $(91.7 \%)$ had no substitute for small ruminant meat; but only about $87.5 \%$ of the respondents considered the meat as normal goods; while it was inferior goods to about $12.5 \%$ of the sample.

Table 4. Proportion of expenditure/income that goes into small ruminant's consumption.

\begin{tabular}{lll}
\hline & $\begin{array}{l}\text { Mean } \\
\text { Expenditure on } \\
\text { small } \\
\text { ruminants } \\
\text { N }\end{array}$ & $\begin{array}{l}\text { Proportion of } \\
\text { expenditure/income that } \\
\text { goes into small ruminant's } \\
\text { consumption (\%) }\end{array}$ \\
\hline $\begin{array}{l}\text { Mean expenditure } \\
\text { on small ruminant } \\
\text { meat }\end{array}$ & 9810.72 & 14.98 \\
$\begin{array}{l}\text { Mean income of the } \\
\text { households }\end{array}$ & 65471.67 & \\
\hline
\end{tabular}

Table 4 shows the ratio of respondents' expenditure on small ruminant to the income. The result shows a ratio of 0.1498 . This implies that consumers of small ruminant in the study area spend as much as about $15 \%$ of their total income to purchase small ruminant meat.

\subsection{Determinants of Willingness to Pay for Small Ruminant Meat}

This section presents results of Logit regression analysis of the determinants of the willingness to pay for small ruminant meat among households in the study area. The results are presented in Table 5 .

The results of the maximum likelihood coefficients from the logit estimation (table 5) indicate that four (4) out of the 14 variables included in the model have a statistically significant influence on the probability of willingness to pay for small ruminant meat. These variables are age of the household head, occupation, distance from market, and price of small ruminant meat.

The coefficient of age $(0.121)$ is positive and significant at $\mathrm{p}<0.05$. This shows that advancement in age of a household head tends to increase the likelihood of the household's willingness to pay for small ruminant meat. The marginal effect of one year advancement in the age of a household head on willing to pay for ruminant meat is 0.20 . The coefficient representing the occupation of the respondent $(-0.18)$ is negative but significant at $\mathrm{p}<0.05$. This shows that the likelihood of a household's willingness to pay for small ruminant meat reduces with increase involvement of the household in livestock farming. 
Table 5. Logit regression result of willingness to pay for small ruminant meat.

\begin{tabular}{llll}
\hline Variable & Parameters & t value & Marginal effect \\
\hline Constant & 3.37 & 0.70 & 0.55 \\
Educational level & -0.15 & -0.94 & -0.25 \\
Age (year) & $0.12^{* *}$ & 2.13 & 0.20 \\
Household income & -0.86 & -0.35 & -0.14 \\
Dependency ratio & -1.37 & -1.58 & -0.22 \\
Marital status & 1.10 & 1.20 & 0.18 \\
Sex & 0.27 & 0.45 & 0.44 \\
Consumer preference & -0.79 & -0.01 & -0.13 \\
Religion & -0.63 & -1.04 & -0.10 \\
Occupation & $-0.18^{* *}$ & -2.15 & -0.30 \\
Distance from market & $-0.91^{* * *}$ & -3.94 & -0.15 \\
Availability of ruminant & -0.16 & -0.02 & -0.27 \\
meats & & 1.97 & 0.70 \\
Price of ruminant meat & $0.42^{* *}$ & -1.09 & -0.30 \\
Household size & -0.18 & -0.95 & -0.15 \\
Quality of ruminant meat & -0.94 & & \\
Sigma & 0.15 & & \\
Log likelihood function & 59.85 & & \\
\hline
\end{tabular}

Note: $* * * * *$ and $*$ denotes p-value at $1 \%, 5 \%$ and $10 \%$ level respectively

The coefficient of the distance from respondent's home to the market $(-0.91)$ is also negative and significant $(\mathrm{p}<0.05)$ in explaining the probability of willingness to pay for small ruminant meat. This implies that the longer the distance a household will cover before buying small ruminant meat, the lower the likelihood of household $(-0.15)$ to be willing to pay for small ruminant meat. The coefficient of the current price of small ruminant meat $(0.42)$ is positive and significant $(\mathrm{p}<0.05)$ in explaining the probability of willingness to pay for small ruminant meat. This implies that the higher the current prices at which household are buying small ruminant meat, the higher the likelihood of household to be willingness to pay for small ruminant meat. This result is contrary to the a-priori expectation of change in quantity demanded to a change in price of normal goods. Also, contrary to results from similar study (Jumaet.al, 2010) who reported a negative coefficient for price of small ruminant in Kenya; this study shows that factors other than the current price of small ruminant meat influence the demand of the meat in the study area. Hence, small ruminant meat can be said to be luxury goods.

\section{Conclusion and Recommendations}

The study concludes that most rural households in the study area are headed by females. The household heads have an appreciable level of literacy with a means of livelihood and mostly in their middle age. These rural households consumed small ruminant meat regularly, well educated about the nutritional value of the ruminant meat and mostly willing to pay the market price of small ruminant meat whenever they are ready to consume the meat. Factors influencing their willingness to pay for small ruminant meat are namely: age of the household head, occupation, distance from market, and price of small ruminant meat. Based on the fore going, the following recommendations were made:

The study results indicate that household consuming small ruminant are mostly headed by women who will not necessarily turn to a substitute when the price of small ruminant meat increases. This would mean that consumption of ruminant meat is an issue of preference and not price change. This would mean that there is a niche market for small ruminant meat. More so, the distance to market play a significant role in the willingness to pay for small ruminant meat. Therefore there is a need to properly identify and establish this market niche and assist both producers and consumers to access it. This would help improve the marketing of small ruminant meat product, providing opportunities for rural communities to generate greater incomes; thus improving the livelihoods of these small livestock keepers. A potential policy option is to establish a number of slaughter houses and small ruminant meat market to consumption area and in various villages to broaden the market as well as providing improved market access to producers.

\section{References}

[1] Bah, M., Cissé, S., Diyamett, B., Diallo, G., Lerise, F., Okali, D \& Tacoli, C. (2003). Changing rural-urban linkages in Mali, Nigeria and Tanzania. Environment and Urbanization, 15(1), 13-24.

[2] Boyazoglu, J.; Hatziminaoglou, I. \& Morand-Fehr P. (2005). The role of the goat in society: Past, present and perspectives for the future. Small Rumin. Res., 60:13-23.

[3] De Vries, J. (2008). Goats for the poor: Some keys to successful promotion of goat production among the poor. Small Ruminant Research, 77(2), 221-224.

[4] Degefu, G.T. (2003). The Nile: Historical Legal and Developmental Perspectives. New York, USA. Pp. 429.

[5] Gomna, A., \& Rana, K. (2007). Inter-household and intra-household patterns of fish and meat consumption in fishing communities in two states in Nigeria. British Journal of Nutrition, 97(01), 145-152.

[6] HosmerJr, D. W., Lemeshow, S., \& Sturdivant, R. X. (2013) .Applied logistic regression (Vol. 398).John Wiley \& Sons.

[7] Idowu, A. O., Ambali, O. I., \& Otunaiya, A. O. (2012). Microfinance and small scale pig business in Osun State, Nigeria. Asian Journal of Business and Management Sciences, $1(9), 1-8$.

[8] International Livestock Centre for Africa ILCA(1991).A hand Book of African Livestock Statistics. Working Document No. 15. August 1991. Addis Ababa, Ethiopia.

[9] Jaitner, J.; Sowe, J.; Secka-Njie, E. \& Dempfle, L (2001).Ownership pattern and management practices of small ruminants in the Gambia - implications for a breeding programme. Small Rum. Res., 40:101-8, 2001.

[10] Juma, G. P., Ngigi, M., Baltenweck, I., \& Drucker, A. G. (2010).Consumer demand for sheep and goat meat in Kenya. Small Ruminant Research, 90(1), 135-138.

[11] Kathiravan, D. G., Thirunavukkarasu, M., \& Michealraj, P. (2007). Willingness to pay for annual health care services in small ruminants: The case of south India. Journal of Applied Sciences, 7(16), 2361-2365. 
[12] Kumar, S.; Vihan, V. S. \& Deoghare, P. R. (2003).Economic implication of diseases in goats in India with references to implementation of a health plan calendar. Small Rum.Res., 47:159-64, 2003.

[13] Langyintuo, A.S., Ntoukam, G., Murdock, L., Lowenberg-DeBoer, J., Miller, D.J. (2004).Consumer preferences for cowpea in Cameroon and Ghana. Agricultural Economics 30: 203-21

[14] Nwosu, C. O., Madu, P. P., \& Richards, W. S. (2007). Prevalence and seasonal changes in the population of gastrointestinal nematodes of small ruminants in the semi-arid zone of north-eastern Nigeria. Veterinary parasitology, 144(1), $118-124$.

[15] Otunaiya, A. O., \& Shittu, A. M. (2014). Complete household demand system of vegetables in Ogun State, Nigeria. Agricultural Economics (Zemědělská Ekonomika), 60(11), 509-516.
[16] Shalander, K and Pant, K.P (2002).Goats in India: Status and Technological Possibilities for Improvement In: Birthal, P. and ParthasarathyRao, P. (eds) (2002) Technology options for sustainable livestock production in India: proceedings of the Workshop on Documentation, Adoption, and Impact of Livestock Technologies in India, 18-19 Jan 2001, ICRISAT Patancheru, India. New Delhi 110 012, India and Patancheru 503 324, Andhra Pradesh, India: National Centre for Agricultural Economics and Policy Research and International Crops Research Institute for the semi-Arid Tropics. 220 pp.

[17] ThammiRaju, D. and Suryanarayana, M.V.A.N. (2005). Meat consumption in Prakasam district of Andhra Pradesh Livestock Research for Rural Development 17 (11) 2004

[18] York, R., \& Gossard, M. H. (2004). Cross-national meat and fish consumption: exploring the effects of modernization and ecological context. Ecological economics, 48(3), 293-302. 